DOI: https://doi.org/10.47405/mjssh.v5i12.600

\begin{tabular}{|c|c|}
\hline & Malaysian Journal of Social Sciences and Humanities (MJSSH) \\
\hline Malaysian Journal of & Volume 5, Issue 12, December 2020 \\
\hline $\begin{array}{l}\text { Humanities } \\
\text { (MJ. Sst) }\end{array}$ & e-ISSN : 2504-8562 \\
\hline & $\begin{array}{l}\text { Journal home page: } \\
\text { www.msocialsciences.com }\end{array}$ \\
\hline
\end{tabular}

\title{
Holacracy and Hierarchy Concepts: Which One is More Effective in an Organizational Leadership and Management System?
}

\author{
Parwiz Mosamim ${ }^{1}$, Sinta Ningrum ${ }^{1}$ \\ ${ }^{1}$ Faculty of Social and Political Sciences, Universitas Padjadjaran, Indonesia \\ Correspondence: Parwiz Mosamim (parwizmosamim8@gmail.com)
}

\begin{abstract}
This paper discusses the importance of installing holacracy practices in the organizations' core values instead of hierarchy. Since the organizational structures of holacracy and hierarchy are different, the current study aims to compare the functions of both concepts in terms of the management system. Holacracy suggests a more decentralized structure, while hierarchy stands on a centralized one. In holacracy concept, power moves from leaders to processes in an organization as a whole. Further, holacracy also provides a concrete framework for encoding autonomy, agility, and purpose-alignment into the organization's DNA. Somehow holacracy replaces the conventional management hierarchy with a new structure. In holacracy, instead of operating top-down, power is distributed throughout the organization - giving individuals and teams freedom while staying aligned to the organization's purpose. This concept has recently been accepted \& implemented in some organizations worldly. In this case, the current study aims to concentrate on the main values of holacracy and finds out that what it can really bring for the organizations.
\end{abstract}

Keywords: holacracy, hierarchy, management, leadership, organizational structure

\section{Introduction}

The current paper discusses and argues that more open space and shared-vision organizational management can function better than a top-down system of management in today's organizations. Since nowadays organizations are looking for well-qualified and well-behaved employees, it is absolutely a desire for the employees and staff as well to be heard accordingly. The author of the paper is comparing two systems of management and leadership in organizations in which the concepts of both organizational structures are different. The study concentrates on the Hierarchy concept (as a more traditional system of management $\&$ leadership) in comparison to Holacracy (a modern practice of management \& leadership) in organizations.

Holacracy is not a model, idea or theory, but it is for sure a practice. (B. J. Robertson, 2007) Robertson discuses that practice is something we engage in, something we do, and something which affects us when we do it - like weightlifting, or mediation, or any of the thousands of transformative practices we engage in(B. J. Robertson, 2007). It is mentionable that holocratic organizations are known as governance structures where the distribution of power among self-organizing groups instead of the top-down authority in the typical hierarchical corporate culture model matters (K. Kinneen, Younas, \& Lücke, 2018). 
Holacracy has been suggested as a new social technology in the era of management systems for organizations(B. J. Robertson, 2006). Van De Kamp (2014), states that holacracy is a governance structure for companies or organizations, which thoroughly changes specific practices that have been built into organizations in the last century. These practices include top-down hierarchy, bottom-up hierarchy, and cooperative structures. In each case, there is a need for management(B. J. Robertson, 2006). Holacracy also promises an emaciated acceptable organization, highly effective, distributed authority and purpose-driven work(B. Robertson, 2007). As of 2014, only small and medium-sized enterprises (SMEs) have adopted this strategy.

Holacracy management concept stands against hierarchy (see figure2). Dr. Michael Y.Lee argues that In Holacracy, you see groups making proposals to revise the design of their group and of the broader organization(Van de Kamp, 2014). They're making decisions that a typical organization, instead a hierarchical organization (see figure1) can only make at the management and senior management level. Holacracy mostly pays attention on the roles, responsibilities and talent of the employees in the organization. It can be called as "The Game Rules" where everyone plays his/her own role in the organization(Weller, n.d.).

Holacracy replaces the management hierarchy with a way of operating that sets clear expectations and creates transparent authority at every level in the organization(Lee \& Edmondson, 2017). This reduces inefficiencies and undercuts hidden power dynamics throughout the organization. In this regard, David Allen (David Allen, Author of Getting Things Done) gives a very simple example about the concept of holacracy. He says that the structure allows you freedom. Mostly like the structure in the roads. If it's a fair structure, it lets you to think about other things while you are driving $(\mathrm{K}$. Kinneen et al., 2018)

One of the good things about the holacracy is this that the roles and responsibilities of the staff in the organization are transparent and clear(Golden, Pandey, \& O'Rourke, 2019). Static job descriptions and corporate titles become dynamic roles and responsibilities that are transparent and evolve as the organization changes(Reilly, 1998). This clarification helps organizations measure while simplifying work and sustaining specific ownership. Ruben Timmerman, Founder of Springest ${ }^{1}$ declares that he has an organization where 50 people work and more than 300 roles are divided among them and still people can just find the right person for something for the first day and it seems as a magic. In a sum or general definition of holacracy, Eric Babinet says that Holacracy is a real-world-tested approach for structuring, governing, and running a purpose-driven, agile organization (Schreiber, 1998). He does believe that it creates an organization where everyone has greater clarity, autonomy and empowerment, and the organizational structure is continually evolving to meet the needs of the business(Krasulja, Radojević, \& Janjušić, 2016).

Figure 1: Holacracy vs. Hierarchy

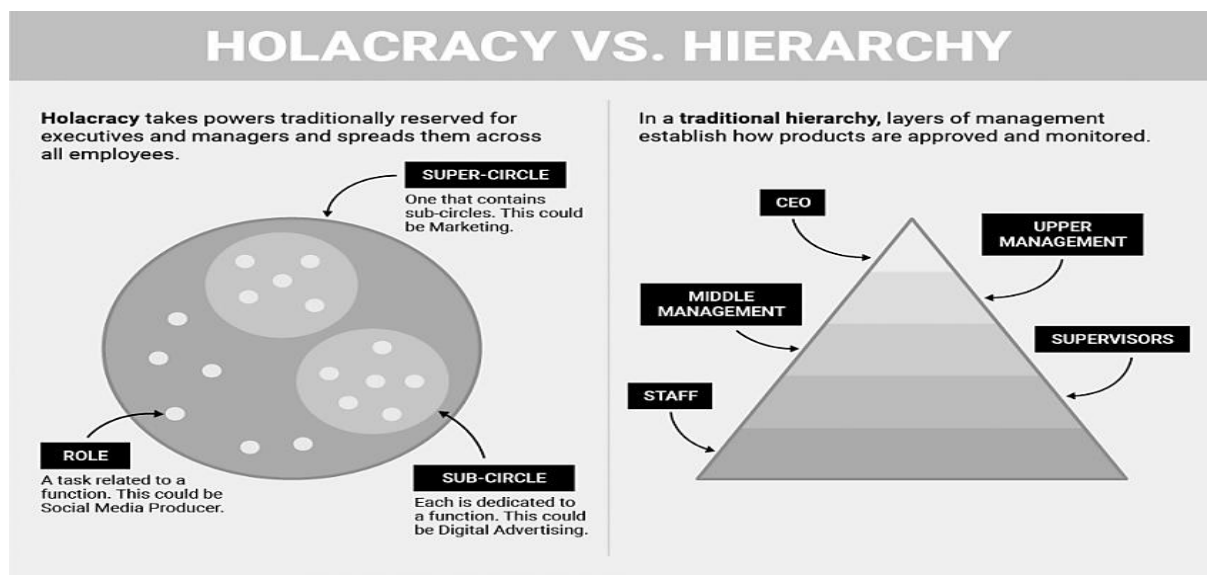

Source: https://corporate-rebels.com/workshop-holacracy/

${ }^{1}$ Springest is the leading European learning platform for organizations 
According to figure 1, Holacracy is a system for organisational governance. It defines a framework of "roles" by which the people of a team work together. The team members then use this frame to discuss and decide together how they want to function together exactly. They constantly inspect and adapt their way of working. Holacracy certifies an effective, constructional and specific process for this process of self-organisation. As aforementioned, all members (employees, shareholders, and partners) of the organization are contained in a non-hierarchical structure. However, the organization is distributed in a series of circles.

Holacracy is basically based on the concept of ongoing contention of all employees despite its depending to a clear circle. Peer to peer group meetings from all circles involve discussions on problems, opportunities, tensions, accountability, and expectations. It clarifies what the job tasks of an individual would be as well as the mutual expectations of colleagues. An employee is given freedom to take actions within their roles of responsibility(Kenneth Kinneen \& Younas, 2018). Since holacracy concept is widely discussed nowadays in some of the national and international organizations around the globe, it raises some hypothesis as well. For the current research, I would like to mention some of them as the following:

i. It seems that some organizations in $21^{\text {st }}$ century are interested to look after a modern concept of management instead of hierarchy due to its limitations.

ii. It looks that holacracy concept provides employees a very open space to be part of organization's decisions and be heard in whole.

iii. Accepting a holacracy concept in an organization is more related to the commitment of leaders and employees on shared main goals of organization.

To look for logical answers and information for the above hypothesis, the author mentions some questions in this research paper as the following:

\section{Research Questions}

i. Why Holacracy concept is important in organizations?

ii. What does the Holacracy differ from the Hierarchy concept?

iii. What can Holacracy do for organizational structure, management and leadership systems which Hierarchy is not able to?

\section{Literature Review}

The metaphor of the holonic (holacracy) systems have been the subject of research for more than twenty years, exploited with different semantics in the fields of Organization, Management and even Computer Science(Ravarini \& Martinez, 2019). Amongst the organizational studies, scholars have been introducing different terms along time, such as the holonic enterprise (McHugh 1995), the virtual organization (Mowshowitz 1994), self-organization (Ulieru 2004). Such terms share the common aim of introducing and explaining a model of an organization with weak social linkages and continuously evolving structures, control mechanisms, and - ultimately - power balance. In fact, we can ascribe this stream of research within the always on-going debate about centralized versus distributed governance, where the holonic system represents a metaphor supporting the ideal of the decentralized governance model.

Holacracy concept was introduced by Brian Robertson and Tom Thomison in 2007 in the United States of America(Krasulja et al., 2016). Pursuant to Omics group (2017), holacracy is mostly like a social terminology as well as a system of organizational governance where decisions are made in a team and authority is entitled all over organizational teams rather than deposited to top level management (K. Kinneen et al., 2018). The epithet holacracy is taken from Holarchy by Arther Koestler in 1967 as mentioned clearly in his book "The Ghost in the Machine". The book talks about 
Holon which means the part and whole at the same time. Ken Wilber (an American philosopher \& writer) since then widely used the term Holarchy(Mella, 2009). However the term holacracy has been introduced in relatively recent times (Robertson 2007); authors identify altogether that in fact it illustrates the existence of several different organizational models that have in common the objective to overcome the limitations of hierarchy. Robertson (2007) explains holacracy as on organizational structure made of self-organizing teams, called 'circles' (see the figure6) or "holons" that overall create a holarchy always evolving, leading to what he calls a "natural hierarchy concentrated on work in lieu of individuals"(Mella, 2009).

Holacracy - or in German "Holokratie" - is a relevant new concept of organisation, which flashes back in its original approaches to the Austrian-Hungarian writer Arthur Koestler, who declared the Holon concept with his book "Das Gespenst in der Maschine" (1968). He created the term from the Greek word hólos = whole and the suffix on, which should point to the partite or particle character (Reflect, 2016). Yordanova (2014) declares that holacracy is a management and decision-making process which is applied based on predefined rules which are found in the governance tactical meetings. This action is implemented by employees or volunteers of an organization with a concentration on creating detailed clear plans. Her results show the advantages, as well as furnish the key sectors where the method can be performed.

Tony Hsieh; the Zappos CEO in 3013, agreed to accept holacracy based on findings of a research that shows, each time the size of a city doubles, innovation or productivity per resident increases by 15\%(B. J. Robertson, 2015). But when organizations get bigger, innovation or productivity per employee totally goes down. Zappos is mainly structured more like a city, and less like a bureaucratic organization. Julia Fadler and Franz Schwarenthorer argue that if an organization adopt the following questions, it means that the organization has turned the method of leadership and management from traditional way to a new approach. A company without a boss? A team without a leader? A way of working independently, just like you consider it to be most convenient? Have you heard those questions before? They continue that one clear approach admitting the ideas of self-organization and try to work for an organization's purpose is Holacracy. (Iqbal \& Kureshi, 2016)

Brain Robertson has defined holacracy as a term of Sociocracy, which is known as a system of governance in the second half of the $20^{\text {th }}$ century and it brought much inspiration (Serrini, Turner, \& Brunetta, 2018). This term inspired the improvement of circle structure and governance process within holacracy. Holacracy is made for organizations and distinguishes the organizational roles from the people working in it(Viðarsson, 2017). However, David Allen from David Allen Company states that holacracy is not a universal solution; it won't resolve all of an organization's tensions and dilemmas. But in Allen's experience, "it does supply the most sustained ground from which to define, frame and address them.'”(B. J. Robertson, 2015).

To date, organizations are confronting many challenges, such as maximizing profits, minimizing expenses and looking for the well qualified staff to keep things move integrated, the above challenges are for both Self-Management organizations (SMOs) and larger corporations that require new and untraditional strategies(B. Robertson, 2007). In this cases, many organizations regardless of size have accepted the holacracy model as to achieve performance efficiency(Velinov \& Denisov, 2017). Many organizations function in a knowledge-based economy where ideas and expertise entail of primary sources of value creation in opposition with the production of goods. There is a greater need for a knowledge economy for employees at all levels to recognize information and ideas for a successful organization. Therefore, the tension model of the holacratic system is best appropriate to the entrepreneurship(Van de Kamp, 2014).

Bernstein, Bunch, Canner and Lee (2016) believe that leaders need to be both trusty and conformable(Magpili \& Pazos, 2018). This is because situations call for many small alignment in making or construction in order to meet local needs, while others call for essential shifts in strategy and sufficiency. Organizational members should have a sustained working space, access to vital resources, and specific goals and responsibilities(Kozlowski \& Bell, 2012). The idea for selfmanagement teams created in the 1980s. With the introduction of holacracy, instead of concentrating 
on self-management teams or flat line organizations, why doesn't the whole company, organization, or institution become self-managed? (Nelis, 2018).

\section{How do Self-Management Organizations Function?}

Self-managing organizations (SMOs) are known as those which radically decentralize power in a formal and systematic way all over the organization(Elman, 2018). SMOs remove the hierarchical reporting relationship between manager and subservient that serves as the core building block of the managerial hierarchy (see figure2). This vocalize a key system of control. In addition to that, all employees hold well-defined decision-making processes, thus giving them responsibility and self-rule side by side. Davis, Eisenhardt, and Bingam (2009) found out that speed, uncertainty, unpredictability, and complication are different environmental dynamics that affect performance(Davis, Eisenhardt, \& Bingham, 2009). Increasing unpredictability guides to decreasing structure and low to moderately structure leads to the implementation of tasks. Small organizations with little structure lack guidance to make suitable behaviors efficiently(San Cristóbal, Carral, Diaz, Fraguela, \& Iglesias, 2018). Yet, larger organizations with strict structures are compelled and lack inflection (Volberda, 1997).

Figure 2: Three Myths about SMOs

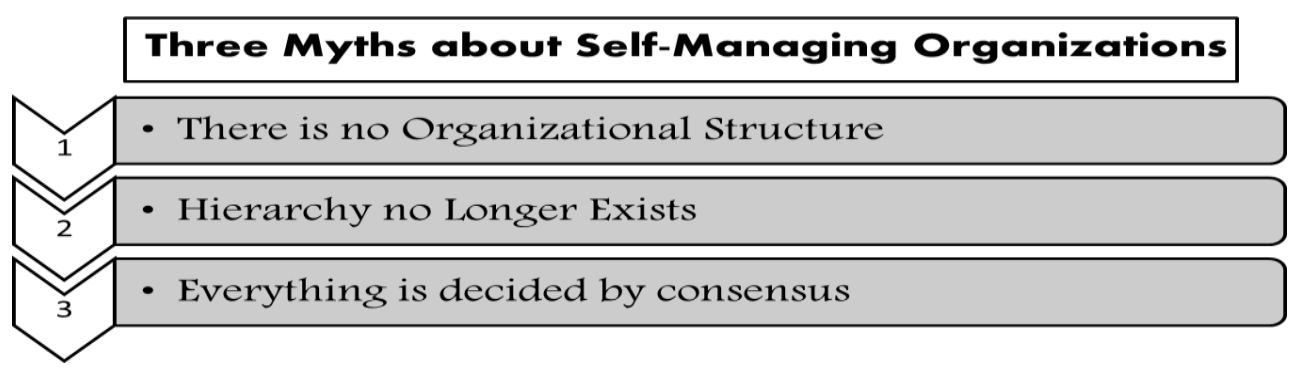

Source: (Bernstein, Bunch, Canner, \& Lee, 2016)

Kurki \& Willenius (2016) featured in their paper that organizing meetings have an indirect relationship with the new key technologies. As a result, new forms of management organizations like holacracy are evolving (Walz, Lindsay, Soni, \& Libraries, n.d.). According to longitudinal surveys, less than $20 \%$ of Fortune 1,000 companies had team-based structures in 1980, compared with $50 \%$ in 1990 and $80 \%$ in 2000(Hollenbeck, Ellis, Humphrey, Garza, \& Ilgen, 2011). Kurki states that these companies want to accept a new management style to be more effective and to achieve higher growth, through more qualified employees. This can be achieved as well through a new management style that partition the employees into small functional groups in which each group can take a decision and share in the decision-making process about the strategic plans regarding the company.

Arthur Koestler describes Holon as a component in a hierarchy, which - depending on the point of view - behaves as a whole or as parts. He states that a very good example of a Holon is the human cell, which itself can be seen as a whole and at the same time represents only a part of the emperor structure. Joined with this definition, American entrepreneur Brian J. Robertson adopts the Holon concept as the basis for his organizational concept of "holacracy". This includes the practice of regulating and managing organizations, which is characterized by decision-making based on transparency and participatory opportunities for participation at all levels. In this case, holacracy assists organizations prosper more easily in a world that is becoming increasingly subtle and dynamic. The purport of holacracy is that every person in the organization becomes a manager, which supports commitment and flexibility. Specific structures, roles and decision-making processes generate a wellorganized system instead of anarchy.

A research study declared that only $10 \%$ of people are interested to think about their goals regularly, while only 1 to $3 \%$ of people have clear written goals(Campbell, 2003). If goal-setting is such significant and powerful, why don't more people use it? Absolutely there are many reasons for it, as you clear to set goals with your employees or staff in an organization, it is important to know much about the goals-setting (see figure3). Setting goals can help us to get what we want, but we have to be 
clear about what that is before the goal-setting process can work. To understand why goal-setting matters to an organization, it's important to distinguish the differences among mission, goal, objective, and task.

Figure 3: Definitions on mission, goal, objective and task in organizations

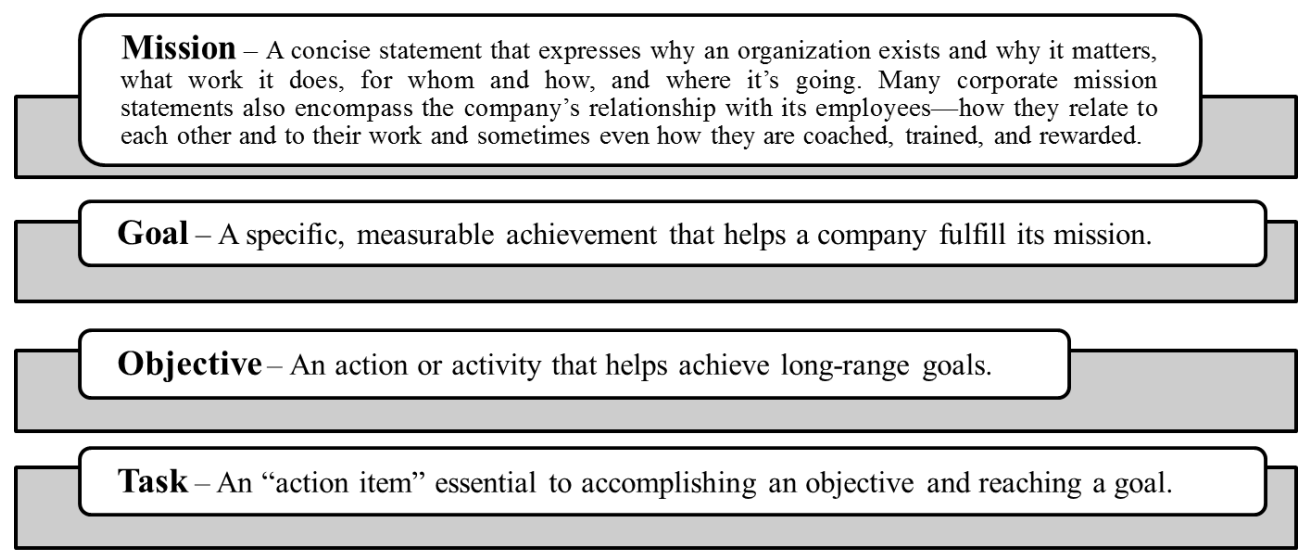

Source: (Campbell, 2003)

The following figure explains how the managers in the organizations should think out of the box and give space to the employees to achieve the targets and goals of the organization in a short time period. Since holacracy concentrates on the roles in the organizations, figure4 clearly guides the managers to figure out all aspects of setting-goals in terms of defining individual role in the circle of the organization's rules.

Figure 4: Outside the Box (the way managers should set the organizational goals)

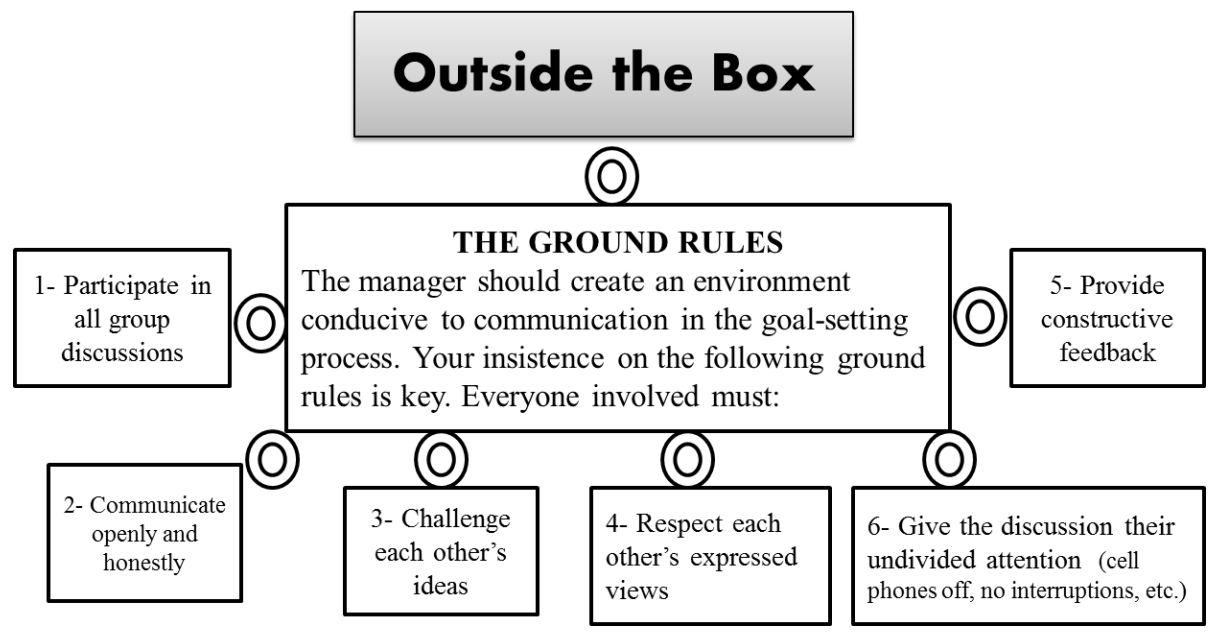

Source: (Campbell, 2003)

\section{What can Holacracy bring in the organizations that Hierarchy cannot?}

In Holacracy, a hierarchical pyramid structure is replaced by a structure of circles and sub-circles (see figure1). In holacracy concept, in each circle there are special roles that connect and coordinate the work of the sub-circles(Holacracy, 2015). A circle includes of different roles. Each person working in a holacratic organization can take over multiple roles and therefore belongs to more than one circle. In comparison to job descriptions in traditional organizations, roles are changed dynamically in accordance with needs from within the organization or as a reaction to changes from outside. (Holacracy, 2015) 
Holacracy also describes clear decision-making processes and meeting structures to guarantee a coordinated course of function within the circles and the organization as a whole(Archer, ForresterWilson, \& Muirhead, 2016). Weekly tactical meetings are arranged on the circle-level and serve the purpose of checking the circle key performance indicators, exchanging the status of work and addressing tensions arising in the day-to-day operative work. Governance meetings are held on a monthly basis to further develop how work is done in the organization (Which roles do we need? What are ongoing activities that we need to watch?). The overall goal is to go with the flow (see figure5). In an organization - if someone makes a suggestion on how to proceed further, the idea can only be neglected by the others if serious doubts arise.

Figure 5: Work Flow Tools in Organization

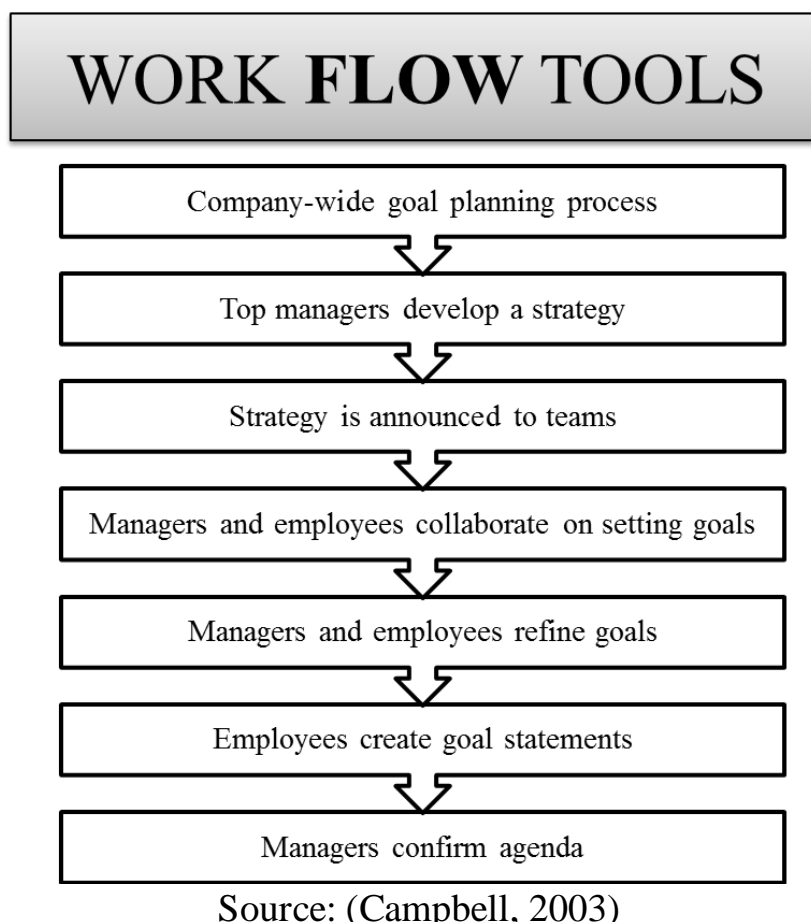

In another definition, Holacracy explores a new tier of organization and culture only recently available to us, and so it is a new practice, one still emerging, and one which takes us into territory still largely unexplored(B. J. Robertson, 2007). Holacracy concept tries to practice engagement and shared-vision in the organizations therefore; here are four major aspects of holacracy (Kumar S \& Mukherjee, 2018).

\section{i. OrganizationalStructure}

Holacracy tiers the frank structure of an organization with its more organic natural form, replacing artificial hierarchy (see figure2) with a fractal "holarchy" of self-organizing teams ("circles") (see figure13). Every circle joins to each of its sub-circles through a double-link, where a member of each circle is nominated to lie on the other, making a tow-side flow of information and fast feedback chains. Each circle rules itself by reveal the roles needed to reach the aim of the circle, and assigning circle members to fill them (see figure 10).

\section{ii. OrganizationalControl}

Holacracy increases organizational speed by improving the methods we use to control organizational activities(Kristensen \& Shafiee, 2019). It helps us make decisions rapidly and incrementally with maximal information, so that we can frame our path continuously as new information appears along the journey. And when it isn't specific what decisions and actions are expected of us, Holacracy encourages us to take individual action using our best judgment, accept ownership of the impact, as well as assistances the organization to know from the experiment. 


\section{iii. $\quad$ Core Practices}

Holacracy's core practices include regular circle meetings for both governance and operations(B. J. Robertson, 2013). Governance meetings help describe how we will work together - they facilitate uncovering and assigning the roles needed to reach the circle's aim. Operational meetings assistance the work to be done - they simplify efficient planning and accomplishment of the circle's day-to-day business. Further, to the core practices, Holacracy sets add-on practices or "modules" which directs many specific organizational processes, from employing to budgeting to project management.

\section{iv. Shared Language \& Meaning}

Holacracy throws in powerful mental models and concepts into the organizational culture, creating a body of culturally shared language and meaning which facilitates ultra-high-bandwidth communication beyond ego.

\section{The way roles change in organizational structure from Hierarchy to Holacracy}

Figure 6 defines an organization which has admitted holacracy as a new concept of management. You can visibly see that the organizational structure is not from top to down, it is a circle where the staff or employees mime a better way of team working.

Figure 6: Example Circle Structure (a practice model of holacracy)

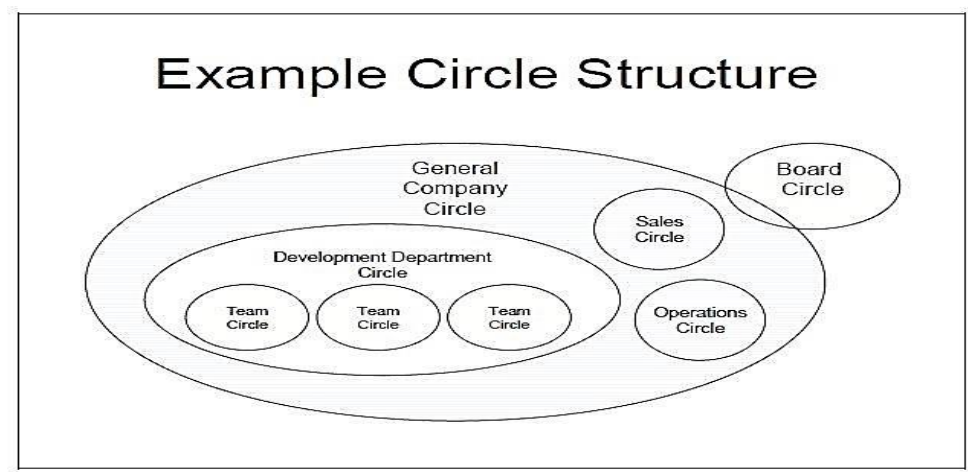

Source: (B. J. Robertson, 2007)

And now let's see figure 8 which describes a more familiar view of the same company's organizational chart. It shows visibly that holacracy does not abolish this traditional organizational chart, however the view is now incomplete and it has a skillfully different meaning within holacracy cultural context.

Figure 7: A Traditional Organizational Chart (a practice model of hierarchy)

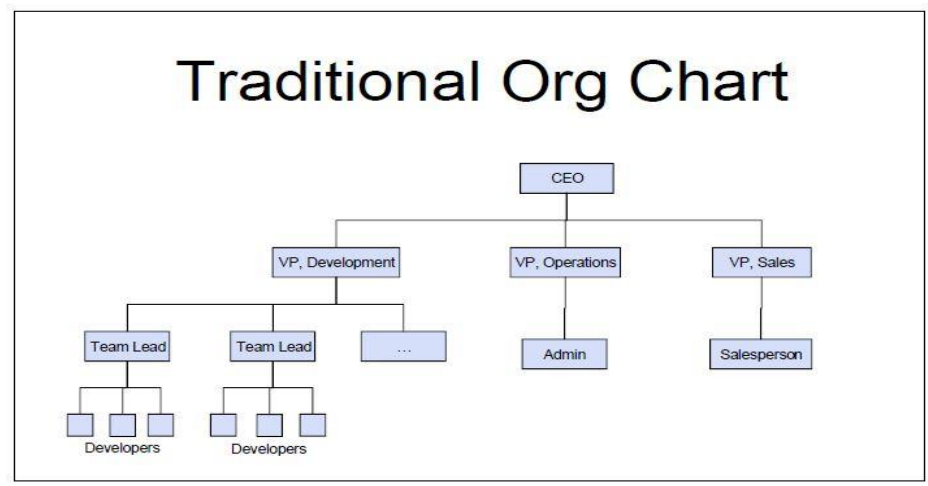

Source: (B. J. Robertson, 2007) 
Figure 8 brings the above views of the organization together, by overlaying the circle structure on top of the traditional organizational chart. It is the same view as Figure 6, just taken from a different angle. This view also shows how a manager serves as a connection or canal between a broader and more concentrated circle (note how both circles overlap the manager role).

Figure 8: From Hierarchy to Holacracy (a change in organizational structure)

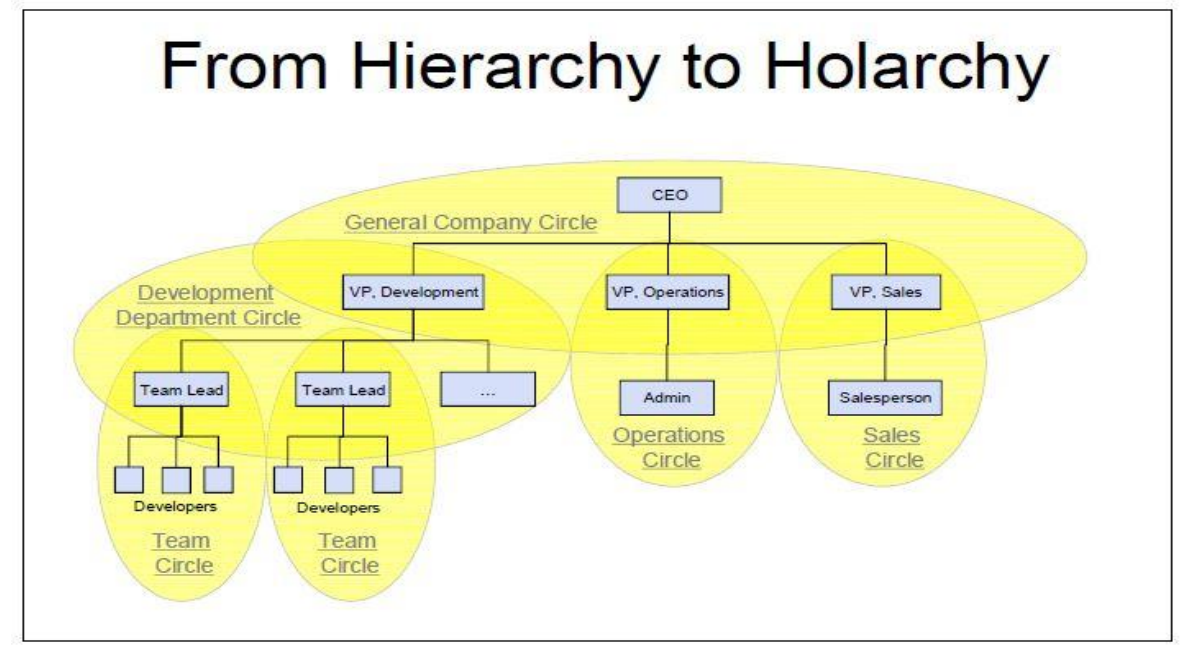

Source: (B. J. Robertson, 2007)

\section{Holacracy - Power to the Process}

With Holacracy, dividing authority is not just a way of taking power out of the hands of a leader and giving it to someone else or even to a group(Canner, Blocks, \& Software, 2015). Rather, the seat of power changes from the person at the top to a process, which is explained in detail in a written constitution. Holacracy's constitution is a public document proper to any organization wishing to use the method; once formally accepted, the Holacracy constitution functions as the core rulebook for the organization(Disclaimer, 2010). Its rules and processes govern high, and domain even the person who adopted it (B. J. Robertson, 2013).

This variation from personal leadership to constitutionally taken power is significant to Holacracy's new model(HolacracyorHolography, n.d.). Even with high determinations and great leaders, a topdown power system guides almost inevitably to a parent-child dynamic between the manager and the employee. Familiar prototypes are almost impossible to avoid; the result is that employees not feel in power and victimized, and managers feel crashed by the sense that relates to them to take care of their responsibilities and value with everyone's tractions. Holacracy states managers, "It's no longer your job to solve everyone's problems and take on responsibility for everything." And it tells workers, "You have the responsibility, and the authority, to content with your own tractions." (B. Robertson, 2007)

Figure 9: Changing the roles from individual to the group

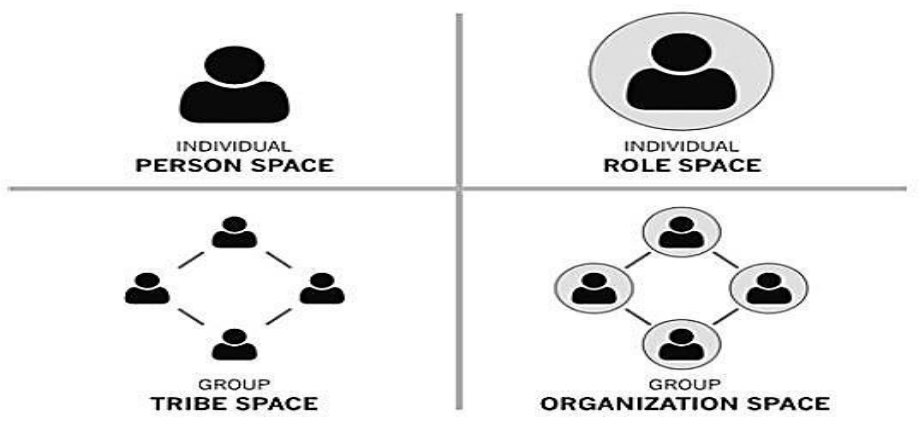

Source: (B. J. Robertson, 2013) 


\section{How does holacracy work in an organization?}

Holacratically organized organizations describe dynamic roles based on work and not on people(Adler, 2001). Employees can therefore take on different roles in different teams, which are dynamically adapted to their daily work stipulations. Decisions are made locally, since power is highly decentralized and teams can therefore work independently and autonomously. Nevertheless, the individual persons and teams do not act completely independently of each other, but are networked with each other through connections ("lead link, "rep link, "cross links"). As an outcome, workers and teams work more autonomously and managers concentrate on strategy and planning instead of operational micromanagement(Kolzow, 2014).

Figure 10: The way Holacracy Concept works in the Organizations

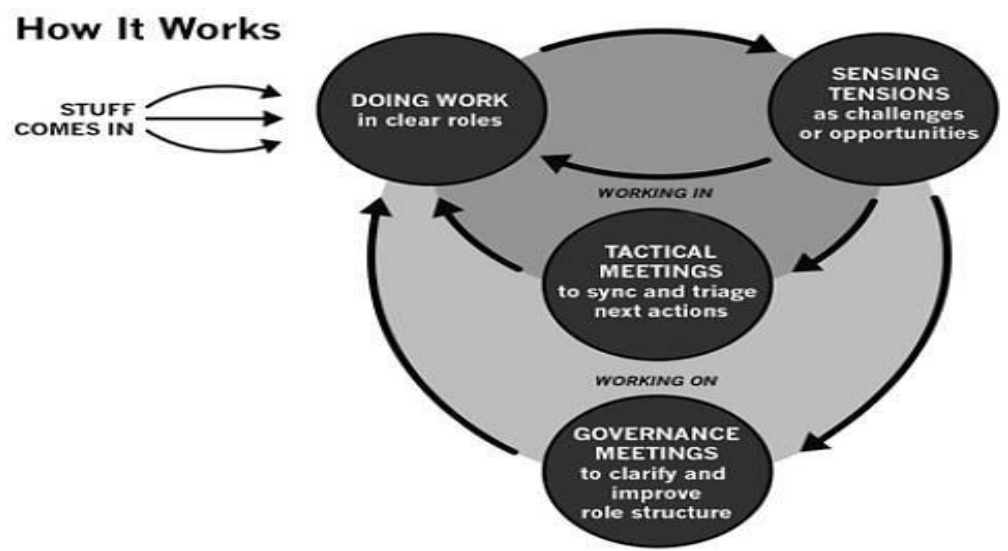

Source: (B. J. Robertson, 2013)

Often the concept of holacracy is explained and adapted as non-hierarchical, managers are abolished(Viðarsson, 2017). However, the holocratic investment is based on ever-growing circles, with internal circles being related to external circles. Roles therefore exist that are entirely hierarchical. This organizational structure is accepted to current challenges in regular team meetings ("governance meetings"). The system is supported by specific and transparent rules that are visible and valid for everyone in the so-called Holacracy Constitution.

Figure 11: The Organizational Structure framework of Holacracy concept

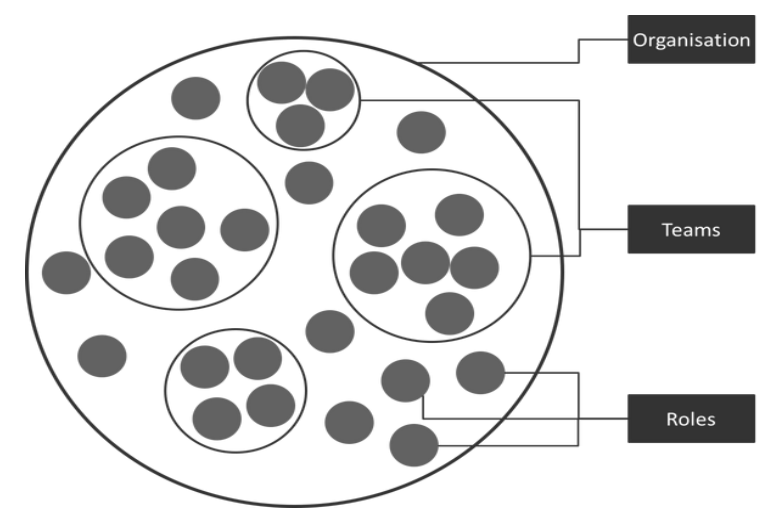

Source: Holocratic organizational design (own presentation based on Robertson, 2016)

The following structure obtains the core shift necessary for Holacracy's repartition of power-from a hierarchy of people leading people, to a holarchy of organizational functions assigned to roles and circles(Borges Gouveia, 2016). And this is a vital difference: a shift not simply in the type of structure, from hierarchy to holarchy, but in what we're structuring in the first place. Holacracy motions from structuring the people to structuring the organization's roles and actions. More specifically, instead of structuring a simple authority relationship between people - who can give orders to whom - Holacracy 
structures where work lives within the overall system, and it clarifies the boundaries between the various essences doing that work. Because of this, I think it can be embroilment to assertion either "Holacracy is flat" or "Holacracy is hierarchical"; Holacracy uses a various type of hierarchy than we're used to, for a different purpose.

Figure 12: Basic Circle Structure in Holacracy Concept

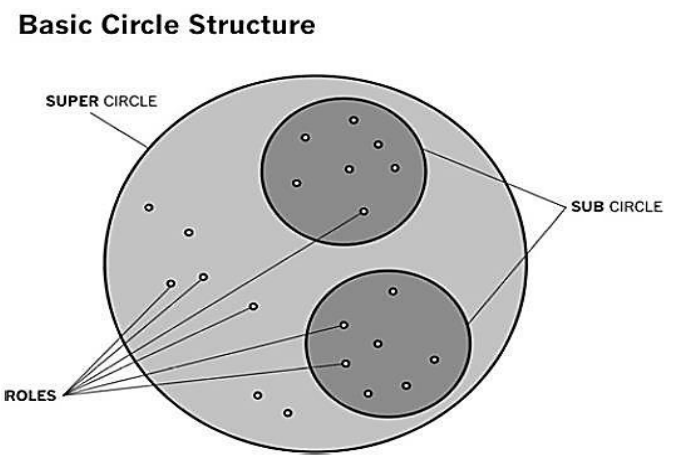

Source: (B. J. Robertson, 2013)

A “ circle" in Holacracy is a self - organizing team(Schreiber, 1998). Each circle has an aim (purpose) and the power to explains and allocate its own roles and accountabilities. Each circle has a breadth of zone that it concentrates on; some circles are emphasized on doing clear projects, others on managing a department, and others on overall business operations.

In another side, the way that hierarchy acts in the organization is totally different than the holacracy concept. Figure 13 visibly shows that hierarchy does not value for the roles in the organization. Also, the organizational structural is not very appropriate for doing group work or team working in the organization.

Figure 13: The way hierarchy concept functions in the organization

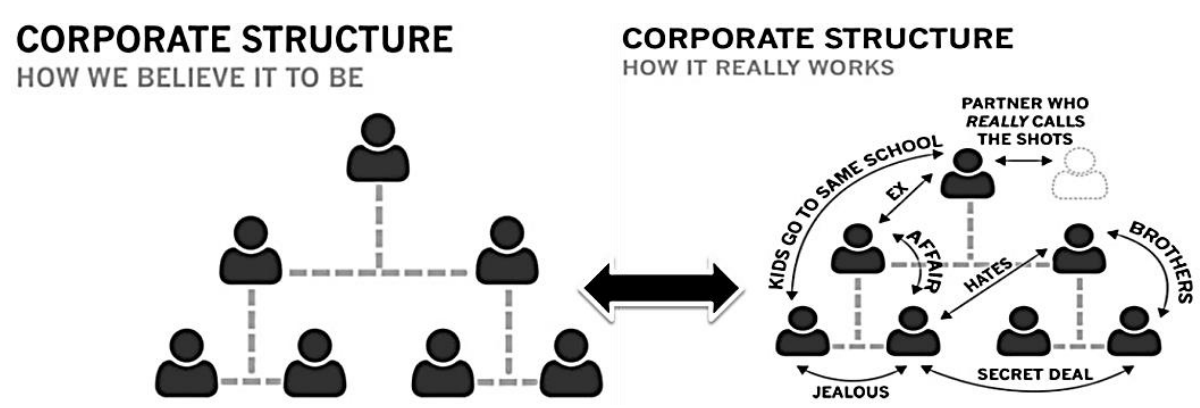

Source: (B. J. Robertson, 2013)

\section{Five Steps to Bootstrap Holacracy}

If an organization is interested to implement the concept of holacracy in its structure, the following steps officially allow the organizations to adopt this concept:

i. Adopt the Holacracy constitution.

ii. Set up a shared system for governance records.

iii. Define your initial structure.

iv. Hold first governance meetings and run elections.

v. Schedule regular tactical and governance meetings. 


\section{Research Methodology}

This research paper employs a qualitative approach using literature review and secondary document reviews. The literature reviews focused on some academic papers and books related to the issues, whilst secondary documents conducted to review the experience of implementing holacracy concept in some organizations. In this paper, the main focus is on providing academic information based on the core values of holacracy concept as well as showing the differences between holacracy and hierarchy concepts by using librarian research methodology according to the experts' knowledge in the era of management and leadership. This research study mostly stands on reviewing the secondary data in a descriptive way.

\section{Discussion}

\section{Holacracy - A heavenly way of working or an overload of structure?}

A lot has been said and written about organizations that have adopted Holacracy. Some share very positive experiences and find relief in clear meeting structures that actually lead to fruitful outcomes. Others are doubtful about the added value of the new operating system and criticize Holacracy for being extremely technical and over-structured. Individual experiences with Holacracy also seem to differ a lot within an organization, as the example of the online shoe and clothing shop Zappos, the largest organization having adopted Holacracy so far, shows. When the company completely changed their internal structures and processes to Holacracy, most employees decided to stay. 29 percent of the staff, however went for the buyout option off ered by Zappos and left the organization.

The wide range of views on Holacracy are shown with the following two quotes: One employee at Zappos stated that “... my worst day at Zappos is still better than my best day anywhere else. I cannot assume going back to traditional hierarchy anymore." A prior worker of the organization called Holacracy “... a social test that generated babel and uncertainty." How can this gap be explained?

The simple answer for the above gap and question can be explained in the way of making a different in the organization. Adopting any kind of concepts of management and leadership require mutualunderstanding on the concept values. It is a natural thought that holacracy concept cannot be implemented in some organizations and one of the biggest reasons is this that the managers or employees are not comfortable with this system of working. Before everything, holacracy calls the organizations on knowing the values of the concept and then start adopting it.

\section{Do you have the right mind-set and skills?}

Holacracy and other approaches fostering self-management demand a certain mind-set and special skills, which might be new or unfamiliar to a lot of people who have been working in traditionally managed organizations for most of their work life(Ehlers, 2020). One of the core skills that have to be developed to profit from self-organization is the ability to work in self-organized teams. This might sound trivial but it is actually a huge challenge. Working in self-organized teams needs clear rules. On an individual level, self-organization requires the ability to give and receive feedback - even (or above all) if it is critical.

Furthermore, it needs an overall attitude of openly sharing with others. For various reasons, we are often used to keeping information to ourselves or do not want to express doubts and fears(Donkor, Slobodjanjuk, Cremer, \& Weisshaar, 2017). In the system of Holacracy, that is not possible: Very clear meeting structures are used to share all the information necessary to guarantee a steady work flow. If decisions have to be made, everyone is responsible for the outcome and can make suggestions or express worries. Bearing all that in mind, Holacracy provides a lot of opportunities for organizations to become places of creative exchange and co-operation, but it also runs the risk of expecting too much from people who are not used or not willing to work without clear instructions by management. 


\section{What can organizations learn from Holacracy?}

Summing up, Holacracy provides some very interesting knowledge. The idea of giving power to the process and providing the necessary set-up for people so they can decide independently in their field of responsibility is definitely a promising path for all kinds of organizations. Thinking about this possibility might trigger an intense process of reflection on what is actually expected from employees: Do we really want our employees to act and decide independently? Holacracy might be criticized for good reasons and the decision in favor of or against adopting this new operating system has to be made by organizations individually. In any case, the approach shows one possible way for organizations to continuously develop their own structures and processes in order to keep up with the pace nowadays.

\section{Conclusion}

To conclude the paper findings; holacracy concept can bring more space of innovation and creativeness ideas in the organizations which hierarchy concept randomly does it. Also, holacracy concept concentrates on the roles of the employees in the organization however; hierarchy just pays attention on the top-down authorities. Holacracy concept of management in its own way is known as one of the most effective concepts for management and leadership in the organization. However, this concept maybe does not fit in each organization and that is due to giving more responsibilities and space for the whole organizational structure. Holacracy concept believes that sharing-vision and decision among the whole staffs in the organization is a way of reaching the organizational goals soon. This concept does not ignore the responsibilities or authority of the manager in the organization, but it suggests an open space of doing group working \& team working which includes each employee's idea and suggestion. Somehow, this concept pays attention on the roles in the organization instead of topdown authorities based on the organizational structure. In this case, the organizations which trusts on an open space of working, this concept is highly suggested to be implemented. However, the organizations which still prefer working based on the hierarchy concept (top-down), holacracy is not suggested to be implemented, because it is against it. To date, holacracy concept is paving the path of success in some international organizations whilst some other organizations which still go ahead with hierarchy, also pave the same path. They only thing which is very significant on implementing each one of the concepts (holacracy \& hierarchy) is the way of thinking on the management system of the organization as well as the policies and strategies.

\section{References}

Adler, P. S. (2001). Market, Hierarchy, and Trust: The Knowledge Economy and the Future of Capitalism. Organization Science, 12(2), 215-234. https://doi.org/10.1287/orsc.12.2.215.10117

Archer, I., Forrester-Wilson, S., \& Muirhead, L. (2016). Exploring Holacracy's Influence on Social Sustainability Through the Lens of Adaptive Capacity.

Bernstein, E., Bunch, J., Canner, N., \& Lee, M. (2016). Beyond the holacracy hype. Harvard Business Review, 2016(July-August).

Borges Gouveia, L. (2016). Holacracy as an alternative to organisations governance. (November).

Campbell, S. (2003). Achieving goal \#6. Biomedical Instrumentation and Technology, 37(5), 306.

Canner, N., Blocks, T. B., \& Software, T. (2015). Is Holacracy the Answer ? 1-5.

Davis, J. P., Eisenhardt, K. M., \& Bingham, C. B. (2009). Optimal structure, market dynamism, and the strategy of simple rules. Administrative Science Quarterly, 54(3), 413-452. https://doi.org/10.2189/asqu.2009.54.3.413

Disclaimer, L. (2010). Introduction : Holacracy ${ }^{T M}$ Constitution.

Donkor, C., Slobodjanjuk, A., Cremer, K., \& Weisshaar, J. (2017). The way we work - in 2025 and beyond. HR Insights - PwC, 1-33. Retrieved from https://www.pwc.ch/en/insights/hr/future-ofwork.html

Ehlers, U.-D. (n.d.). Future Skills-Future Learning and Future Higher Education.

Elman, B. (2018). The Coordination Mechanisms of Self-Managing Organizations An Explorative 
DOI: https://doi.org/10.47405/mjssh.v5i12.600

Case-Study of Three Pioneers. 121. Retrieved from http://sh.divaportal.org/smash/record.jsf?pid=diva2\%3A1222093\&dswid=-3096\%0Ahttp://www.divaportal.org/smash/get/diva2:1222093/FULLTEXT01.pdf

Golden, B., Pandey, A., \& O'Rourke, J. (2019). Zappos: An Experiment in Holacracy. Zappos: An Experiment in Holacracy, (January 2017). https://doi.org/10.4135/9781526489968

Holacracy, I. (2015). Holacracy.

HolacracyorHolography. (n.d.).

Hollenbeck, J. R., Ellis, A. P. J., Humphrey, S. E., Garza, A. S., \& Ilgen, D. R. (2011). Asymmetry in structural adaptation: The differential impact of centralizing versus decentralizing team decision-making structures. Organizational Behavior and Human Decision Processes, 114(1), 64-74. https://doi.org/10.1016/j.obhdp.2010.08.003

Iqbal, S., \& Kureshi, N. (2016). Dissatisfaction With Performance Management System in a Bank; Possible Reasons and Remedies. Journal of Strategy and Performance Management, 4(1), 4-23. Retrieved from http://proxy.library.vcu.edu/login?url=https://search.proquest.com/docview/1778467771?accou ntid=14780\%0Ahttp://vcu-alma-

primo.hosted.exlibrisgroup.com/openurl/VCU/vcu_services_page?url_ver=Z39.88-

2004\&rft_val_fmt=info:ofi/fmt:kev:mtx:journal\&genre=article

Kinneen, K., Younas, S., \& Lücke, G. (2018). Self-Managing Organizations in the context of Entrepreneurial Innovation. 52. Retrieved from http://www.divaportal.org/smash/get/diva2:1228343/FULLTEXT01.pdf

Kinneen, Kenneth, \& Younas, S. (2018). An Insight into Self managing organizations (SMOs). 1-51.

Kolzow, D. R. (2014). Leading from within: Building organizational leadership capacity. In International Economic Development Council. Retrieved from http://www.iedconline.org/clientuploads/Downloads/edrp/Leading_from_Within.pdf

Kozlowski, S. W. J., \& Bell, B. S. (2012). Work Groups and Teams in Organizations. Handbook of Psychology, Second Edition. https://doi.org/10.1002/9781118133880.hop212017

Krasulja, N., Radojević, I., \& Janjušić, D. (2016). Holacracy - the New Management System. The Priority Directions of National Economy Development, (October), 187-196.

Kristensen, S. S., \& Shafiee, S. (2019). Rethinking organization design to enforce organizational agility. 11th Symposium on Competence-Based Strategic Management.

Kumar S, V., \& Mukherjee, S. (2018). Holacracy - the future of organizing? The case of Zappos. Human Resource Management International Digest, 26(7), 12-15. https://doi.org/10.1108/HRMID-08-2018-0161

Lee, M. Y., \& Edmondson, A. C. (2017). Self-managing organizations: Exploring the limits of lesshierarchical organizing. Research in Organizational Behavior, 37(January 2017), 35-58. https://doi.org/10.1016/j.riob.2017.10.002

Magpili, N. C., \& Pazos, P. (2018). Self-Managing Team Performance: A Systematic Review of Multilevel Input Factors. In Small Group Research (Vol. 49). https://doi.org/10.1177/1046496417710500

Mella, P. (2009). The holonic revolution : holons, holarchies and holonic networks : the ghost in the production machine. In Pavia University Press. https://doi.org/10.13140/2.1.1954.5922

Nelis, A. M. (2018). Decision Making in Self-Managing Organisations and its Implications on Conflict Management. (487978).

Ravarini, A., \& Martinez, M. (2019). Lost in Holacracy? The Possible Role of e-HRM in Dealing with the Deconstruction of Hierarchy. 63-79. https://doi.org/10.1108/s1877-636120190000023006

Reilly, A. J. (1998). Three Approaches to Organization Learning. The Pfeiffer Library, 16(2), 21-25.

Robertson, B. (2007). Feature Article: Holacracy ${ }^{T M}$ in Action: Theory to Practice Example of Double Linking.

Robertson, B. J. (2006). Holacracy: A Complete System for Agile Organizational Governance and Steering Access Experts to the About Cutter Consortium. Management, 7(7), 1-22.

Robertson, B. J. (2007). Organization at the Leading Edge: Introducing HolacracyTM. Integral Leadership Review, 1-33. https://doi.org/10.1007/s

Robertson, B. J. (2013). Holacracy® Constitution (v4.0). HolacracyOne, 0-30. Retrieved from https://www.holacracy.org/constitution

Robertson, B. J. (2015). Holacracy - Discover a Better Way of Working. HolacracyOne, 1-10. 
Retrieved from http://www.holacracy.org/whitepaper

San Cristóbal, J. R., Carral, L., Diaz, E., Fraguela, J. A., \& Iglesias, G. (2018). Complexity and project management: A general overview. Complexity, 2018. https://doi. org/10.1155/2018/4891286

Schreiber, R. (1998). Cluein G in : a G Uid E To So Lvin G Th E Pu Zzle. 269-289.

Serrini, L., Turner, K., \& Brunetta, F. (2018). Rethinking organizations : the Holacracy practice.

Van de Kamp, P. (2014). Holacracy - a Radical Approach to Organizational Design. Elements of the Software Development Process - Influences on Project Success and Failure, (April 2014), 1325. https://doi.org/10.13140/2.1.3740.8645

Velinov, E., \& Denisov, I. (2017). The Relationship between Contemporary Holacratic Models of Management and Company Performance: Evidence from Global Corporations in the World. Global Journal of Business and Social Science Review , 5(2), 10-15. Retrieved from www.gatrenterprise.com/GATRJournals/index.html

Viðarsson, E. R. (2017). Learning Holacracy Fundamentals Through Play.

Volberda, H. W. (1997). Building Flexible Organizations for Fast-moving Markets. Long Range Planning, 30(2), 169-183. https://doi.org/10.1016/s0024-6301(96)00110-0

Walz, A., Lindsay, N., Soni, S., \& Libraries, V. T. (n.d.). Chapter 11 : Managing Human Resources. (July 2016).

Weller, E. (n.d.). On Regulating Decentralized Systems. 